Journal Humanities: Jurnal Pengabdian kepada Masyarakat

Volume 2, Nomor 1, Bulan Juni, 2021.

E - ISSN 2715-5471

Doi: https://doi.org/10.24036/jha.0201.2021.03

\title{
Implementation of Integrated Shuttle Time in Involving and Developing Badminton Sports
}

\author{
Donie $^{1}$, Irfan Arifianto ${ }^{2}$, Hermanzoni $^{3}$ \\ ${ }^{123}$ Fakultas Ilmu Keolahragaan, Universitas Negeri Padang, Indonesia

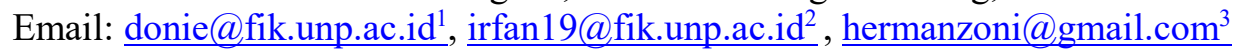

\begin{abstract}
Badminton sport coaching which tends to be instant causes a gap between athletes' achievements in Sijunjung Regency and sports activities for potential athletes of elementary school age. It takes a program that can socialize badminton among elementary school students that is able to foster interest and motivation to play badminton and form a coaching forum into the badminton coaching club. The integrated Shuttle Time program is an effort to socialize and increase interest in playing badminton in elementary school students in general in Sijunjung Regency. The partner in this activity is the Sijunjung Regency Sports Facilities Association (ISORI). The key to implementing badminton with Shuttle Time is to provide badminton lessons that are cheaper, more interesting, fun and safe for elementary school students. The method used in this activity is through several stages, namely the first stage of direct field observation and coordination with related parties in this activity. The second stage provides Shuttle Time training for elementary school sports teachers and the third stage the teacher implements the shuttle time for students. The result of this activity is that the training activities will be carried out for 3 days and the teacher will get provisions in implementing this shuttle time in learning badminton in class hours and extracurricular development activities.
\end{abstract}

Keywords : Shuttle Time, Badminton, Involving

\section{Abstrak}

Pembinaan olahraga bulutangkis yang cenderung instan menyebabkan kesenjangan antara prestasi atlet Kabupaten Sijunjung dengan kegiatan aktifitas berolahraga atlet potensial usia sekolah dasar. Dibutuhkan suatu program yang bisa mensosialisasikan olahraga bulutangkis dikalangan siswa sekolah dasar yang mampu menumbuhkan minat dan motivasi bermain bulutangkis serta membentuk wadah pembinaan ke dalam klub pembinaan bulutangkis. Program Shuttle Time terpadu merupakan upaya untuk mensosialisasikan dan meningkatkan minat bermain bulutangkis pada siswa sekolah dasar umunya di Kabupaten Sijunjung. Mitra dalam kegiatan ini adalah Ikatan Sarana Olahraga (ISORI) Kabupaten Sijunjung. Kunci dari pelaksanaan bulutangkis dengan Shuttle Time adalah memberikan pembelajaran bulutangkis lebih murah, menarik, mengembirakan dan aman bagi siswa sekolah dasar. metode yang dilakukan dalam kegiatan ini adalah melalui beberapa tahapan, yaitu tahap pertama observasi ke lapangan secara langsung dan koordinasi dengan pihak pihak terkait dalam kegiatan ini. Tahap yang kedua memberikan pelatihan Shuttle Time kepada guru olahraga SD dan tahap ke tiga guru mengimplementasikan shuttle time tersebut kepada para siswa. Hasil dari kegiatan ini adalah terlaksananya kegiatan Pelatihan akan dilaksanakan 3 hari dan guru mendapatkan bekal dalam mengimplementasikan shuttle Time ini dalam pembelajaran bulutangkis di dalam jam pelajaran dan kegiatan pengembangan ekstrakurikuler

Keywords : Shuttle Time, Bulutangkis, Pemassalan

\section{ANALISIS SITUASI}

Permasalahan utama saat ini adalah Kecenderungan pembinaan olahraga bulutangkis secara instan (Harper, 2012) dimana prestasi diraih tidak diperoleh dari sebuah pembinaan yang berjenjang, namun hanya menggunakan atlet luar Kabupaten yang sudah jadi. 
Journal Humanities: Jurnal Pengabdian kepada Masyarakat

Volume 2, Nomor 1, Bulan Juni, 2021.

E - ISSN 2715-5471

Doi: https://doi.org/10.24036/jha.0201.2021.03

Akibatnya terputusnya mata rantai pembinaan karena (1) kurang tersosialisasinya olahraga bulutangkis pada atlet potensial khususnya yang berada pada bangku pendidikan Sekolah Dasar. Disamping itu (2) belum adanya wadah pembinaan yang menampung dan membina atelt bulutangkis potensial untuk dibina menjadi atlet andalan produk asli dari pembinaan bulutangkis di Kabupaten Sijunjung.

Program Shuttle Time merupakan salah satu program dari Induk bulutangkis dunia (BWF) yang dirancang dan diciptakan untuk bisa mensosialisasikan olaraga bulutangkis menjadi suatu aktifitas yang murah, meriah, menarik dan dan aman sehingga akan menumbuhkembangkan minat generasi muda khususnya usia sekolah dasar untuk senang dan mencintai berolahraga bulutangkis (Woodward, 2011). Jika bulutangkis telah tersosialisasi dengan baik akan tumbuh minat dan motivasi siswa untuk bermain dan berlatih bulutangkis. Kemudian barulah dibentuk wadah pembinaan dalam bentuk klub bulutangkis yang membina anak anak potensial (Sekolah Dasar) untuk berlatih bulutangkis dengan memperhatikan karakteristik (Drachsler, 2011) serta pertumbuhan dan perkembangan yang sesuai bagi usianya .

Bulutangkis merupakan salah satu olahraga andalan di Kabupaten Sijunjung, ini terbukti pada pelaksanaan Porprov terakhir Kabupaten Sijunjung menjadi Juara umum dengan meraih medali terbanyak. Namun ironisnya para atlet bulutangkis tersebut mayoritas bukan dari buah hasil pembinaan, namun mayoritas berasal dari atlet atlet yang sudah jadi dari luar Kabupaten yang sudah memiliki prestasi yang sudah baik.

Kondisi tersebut bagi Kabupaten Siunjung merupakan seuatu yang sangat ironis karena sebagai pemegang juara umum cabang bulutangkis, pembinaan cabang olahraga bulutangkis di kabupaten Siunjung masih terasa minim. Hal ini terlihat dari lima tahun terakhir daya saing atlet atlet usia dini maupun usia sekolah SD, SMP dan SMA) (Asnaldi, 2019). atlet Kabupaten Sijunjung masih rendah dan belum bisa bersaing dengan daerah lainnya di Sumatera Barat. Tidak membaiknya prestasi atlet muda di Kabupaten Sijunjung salah satunya adalah kurang tersosialisasinya cabang bulutangkis dikalangan anak usia sekolah serta tidak adanya pembinaan bulutangkis untuk atlet muda potensial. Pembinaan atlet yang terstruktur harus dimulai dari anak usia sekolah sebagai pondasi dasar pembinaan jangka Panjang (Asnaldi et al., 2020).

Minimnya kondisi dari lapangan tersebut berdampak pula semakin menurunnya minat masyarakat khususnya generasi muda untuk bermain bulutangkis dan pada akhirnya Kabupaten Sijunjung tidak akan berprestasi lagi dalam olahraga khusunya cabang bulutangkis. Menurunya minat generasi muda dalam berolahraga khususnya bulutangkis dikhawatirkan tidak hanya penurunan kualitas kebugaran jasmani dan kesehatan (BPS, 2018), namun juga generai muda tanpa aktifitas yang positif salah satunya dengan berolahraga cenderung mengisi waktu luangnya dengan hal hal negatif seperti tawuran, narkoba, kebut kebutan dan lain sebagainya.

Menyadari hal tersebut Ikatan Sarana Olahraga (ISORI) merasa perlu menghilangkan kesenjangan antara prestasi atlet senior dengan atlet potensial serta bagaimana bisa menumbuhkan minat generasi muda untuk berolahraga khususnya olahraga bulutangkis dan menata pembinaan bulutangkis melalui pembentukan wadah berlatih bagi bagi para generasi muda yang masih berada dibangku sekolah untuk berlatih dan berprestasi pada cabang olahraga ini (Didik Rilastiyo Budi, Arfin Deri Listiandi, Rifqi Festiawan, Neva Widanita, 2020)(Didik Rilastiyo Budi, Arfin Deri Listiandi, Rifqi Festiawan, Neva Widanita, 2020). 
Ada beberapa pertimbangan mengapa bulutangkis menjadi olahraga yang ideal untuk dikembangkan pada generasi muda usia sekolah :

1) Bulutangkis sama-sama dapat dimainkan oleh baik anak perempuan dan anak laki- laki.

2) Bulutangkis sebagai penyaluran emosi yang positif (Barnett \& Thomas, 2012)

3) Bulutangkis adalah olahraga yang aman dan beresiko rendah bagi anak-anak.

4) Bulutangkis membangun keterampilan olah raga yang mendasar.

5) dari semua kemampuan berhasil dalam dikembangan menjadi keterampilan yang memungkinkannya mereka memainkan bulutangkis ini seumur hidup

6) Pada tingkat sosial, anak laki-laki dan perempuan / pria dan wanita dapat bermain, berlatih dan berkompetisi secara bersama (Papa, 2017).

7) Bulutangkis bisa diakses oleh orang cacat (Woodward, 2011)

Keunggulan dari Shuttle Time ini bagi para pembina baik pelatih maupun guru olahraga pertama adalah tidak memerlukan pengalaman bulutangkis untuk melaksanakan Shuttle Time tersebut artinya semua guru olahraga dapat memberikan materi dari Shuttle Time tersebut. Kedua pelaksanaan Shuttle Time bisa dimodifikasi sesuai dengan ketersediaan sarana dan prasaana bulutangkis di sekolah masing-masing (Omar \& Aman, 2009). Hal ini juga merupakan sebuah solusi dari pembinaan bulutangkis di Kabupaten Sijunjung yang terbatas tidak hanya sarana dan prasarana tetapi juga sumber daya pelatih yang akan mengajarkan atau melatih olahraga bulutangkis tersebut.

Ikatan Sarjana Olahraga (ISORI) Kabupaten Sijunjung melihat peluang dari Program Shuttle Time dalam mensosialisasikan olahraga bulutangkis khususnya pada generasi muda usia sekolah. Menyadari usia Sekolah adalah masa yang paling baik dalam melakukan pembibitan atlet muda potensial untuk dibina menjadi atlet berprestasi nantinya yang akan meningkatkan prestasi olahraga bulutangkis di Kabupaten Sijunjung. Selain itu dengan meningkatnya minat generasi muda berolahraga bulutangkis merupakan salah satu solusi aktifitas positif dalam mengurangi kenakalan remaja di Kabupaten Sijunjung.

\section{SOLUSI DAN TARGET}

Sejalan dengan upaya menarik minat generasi muda khusunysa para siswa sekolah dasar untuk bermain bulutangkis BWF sebagai badan Interasioanl Bulutangkis dunia mengembangkan sebuah program dengan "Shuttle Time is the BWF's Schools Badminton Programme" yaitu program untuk mempopulerkan olahraga bulutangkis di dunia melalui olahraga bulutangkis disekolah. Tujuan dari kegiatan Shuttle Time ini adalah:

- Membantu guru merencanakan dan menyampaikan pembelajaran bulutangkis yang aman dan menyenangkan;

Memastikan anak mengalami kesuksesan dalam bulutangkis;

- Mencapai tujuan umum pendidikan jasmani melalui kegiatan bulutangkis;

- Memungkinkan guru untuk menyampaikan pandangan positif dan pengalaman bulutangkis. (BWF:2011:10).

Melalui Shuttle Time tersebut modul disusun dengan sedemikain rupa untuk semua siswa, semua jenis kelamin dan untuk semua tingkat keterampialn secara menarik, menggembirakan dan aman.

\section{METODE PELAKSANAAN}

Untuk pelaksanaan maka dilakukan beberapa kegiatan yakni ; Memberikan pelatihan Shuttle Time bagi guru olahraga tentang bagaimana mengenalkan permainan bulutangkis disekolah secara lebih menarik, murah dan aman pada siswa di sekolah, sosialisasi Shuttle Time di sekolah, pelaksanaan kompetisi antar pelajar, dan pembentukan klub pembinaan atlet. 


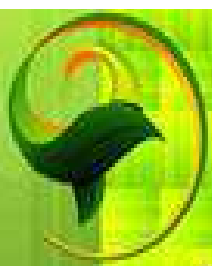

Journal Humanities: Jurnal Pengabdian kepada Masyarakat

Volume 2, Nomor 1, Bulan Juni, 2021.

E - ISSN 2715-5471

Doi: https://doi.org/10.24036/jha.0201.2021.03

\section{PELAKSANAAN KEGIATAN}

Untuk merealisasikan solusi yang telah ditawarkan untuk menyelesaikan masalah kelompok mitra, maka pelaksanaan kegiatan dilakukan melalui enam tahapan. Pertama survey atau penjajakan, dalam tahap ini dilakukan penjajakan dan penentuan lokasi kegiatan pengabdian dan pemilihan kelompok mitra yang membutuhkan bimbingan dalam mengembangkan Iptek keilmuan tim pengusul (Glasow, 2005).

Kedua, orientasi dan diskusi yang dilakukan untuk mengidentifikasi permasalahan yang ada pada kelompok mitra dan mendiskusikan solusi yang dapat dilakukan untuk mengatasi masalah tersebut (Kirca et al., 2005). Disamping itu, juga disusun rencana dan jadwal kegiatan bersama mitra. Ketiga, persiapan pelaksanaan yangmana dilakukan pengurusan masalah perizinan pelaksanaan kegiatan, pemilihan ahli yang dilibatkan.

Keempat, adalah tahap pelaksanaan, kelompok mitra akan diberikan pengetahuan tentang iptek keilmuan yang berkaitan dengan Implementasi Shuttle Time Terpadu. Kelima, tahapan monitoring dan evaluasi berupa kegiatan pendampingan dalam bentuk monitoring dan evaluasi atas pelaksanaan kegiatan pengabdian yang telah dilakukan. Kegiatan ini dilakukan bersama-sama oleh tim pengusul dan mitra dengan jadwal pelaksanaan sesuai dengan yang telah disepakati bersama. Terakhir, merupakan tindak lanjut dengan koordinasi ketua PBSI Kabupaten Sijunjung dan Ketua ISORI Kabupaten Sijunjung dengan ketua tim pelaksana terkait dengan keberlanjutan program.

\section{HASIL DAN PEMBAHASAN}

Kegiatan Sosialisasi Shuttle Time ini dilaksanakan selama 3 hari yang melibatkan 30 guru sekolah dasar yang dlaksanakan secara teori dan praktek, para peserta di bekali dengan modul mulai dari tahap pengenalan sampai modul terakhir bagaimana permainan bulutangkis yang sesungguhnya, lengkap dengan taktik dan strategi permainan. Karena program implementasi ini adalah program BWF yang mendunia maka sudah dikembangkan dalam bentuk aplikasi yang bisa di download dari play Store Smart phone. Hal ini sudah mengkombinasikan pembelajaran yang mengkombinasikan secara tatap muda maupun secara on line (Osborne, 2013). Dihari terakhir guru guru diberikan kesempatan untuk praktek lapangan untuk melihat pemahaman dari guru guru terkait dengan tahapan tahapan pembelajaran (Kirca et al., 2005) terkait dengan shuttle time.

Sesuai dengan target yang diharapkan pada akhir kegiatan ini adalah meningkatnya minat generasi muda usia sekolah untuk berolahraga khususnya olahraga bulutangkis dan meningkatnya pengetahuan dan keterampilan dari guru olahraga dalam memberikan pembelajaran dan pelatihan bulutangkis secara menarik, murah dan aman di sekolah. Minat yang sangat berkaitan dengan kesenangan menjadikan anak-anak melakukan kegiatan tanpa paksaan (Harackiewicz \& Hulleman, 2010).

Dalam kegiatan pengabdian ini terdapat 2 hal yang akan diberikan kepada mitra, yaitu pengetahuan serta teknologi. Dalam hal pengetahuan, mitra akan diberikan informasi tentang informasi bagaimana memberikan pengajaran dan pelatihan bulutangkis dengan pendekatan Shuttle Time. Sedangkan dalam hal teknologi adalah teknologi yang berupa pembaharuan metode latihan dengan Shuttle Time yang menjadikan pembelajaran bulutangkis lebih menarik, murah dan aman bagi siswa (Harackiewicz \& Hulleman, 2010). Kegiatan tersebut akan dirancang sedemikian rupa melalui berbagai tahapan. Untuk lebih jelasnya dapat dilihat dalam alur pelaksanaan kegiatan dibawah ini: 
Perencanaan adalah hal penting yang harus dilakukan karena keberhasilan pelaksanaan sangat ditentukan dengan perencanaan yang baik, perencanaan yang baik harus memenuhi criteria SMART (spesifik, Measurable, Attainable, realistic, timebone ) (Harackiewicz \& Hulleman, 2010). Terkait dengan perencanaan ini penekanannya adalah bagaimana guru membuat sebuah perencanaan yang dituangkan secara tertulis dan digunakan sebagai pedomam pelaksanaan (Science et al., 2013).

Dalam tahap pelaksanaan sebagai inti dari kegiatan implementasi, materi dalam program shuttle time ini betul-betul dirancang dari tahapan termudah sampai pada tahap akhir permainan yang sesungguhnya. Tidak dibutuhkan keterampilan tingkat tinggi dalam pelaksanaan shuttle time namun yang terpenting kegiatan sangan disesuaikan dengan situasi dan kondisi yang ada, berorientasi pada kegembiraan. Tahapan dari yang mudah ke yang sulit merangsang minat dan motivasi anak untuk beraktifitas menyelesaikan tahapan tahapan dalam shuttle time (Takaloo \& Ahmadi, 2017).

Pada tahapan evaluasi lebih menekankan kepada bagaimana partisipasi siswa dalam bermain bulutangkis dan bukan berorientasi kepada kemenangan, partisipasi tersebut dapat dilihat dari kegembiraan dalam bermain, kesungguhan dalam bermain, dan tentu pada akhirnya akan berpengaruh pada kebugaran dari para siswa tersebut. Rasa senang dan bugar adalah modal dasar para siswa dalam berolahraga bulutangkis. Hal lain dari materi shuttle Time adalah sangat memperhatikan aspek tumbuh dan perkembangan si anak dimana seluruh rangkaian gerakan yang ada selalu melatih unsur $\mathrm{ABC}$ (agility, balance, coordination) (Takaloo \& Ahmadi, 2017).

\section{KESIMPULAN}

Program Shuttle Time terpadu merupakan upaya untuk mensosialisasikan dan meningkatkan minat bermain bulutangkis pada siswa sekolah dasar umunya di Kabupaten Sijunjung. Solusi yang diberikan dalam pelaksanaan kegiatan ini adalah memberikan pelatihan bulutangkis dengan pendekatan Shuttle Time. Terpadu yang meliputi : pemberian pelatihan Shuttle Time guru olahraga sekolah dasar, Implementasi Shuttle Time pada kegiatan ekstra siswa di sekolah dasar, kompetisi bulutangkis antar sekolah dasar dan pembentukan wadah pembinaan atlet bulutangkis potensial di Kabupaten Sijunjung.

Kunci dari pelaksanaan bulutangis dengan Shuttle Time adalah memberikan pembelajaran bulutangkis lebih murah, menarik, menggembirakan dan aman bagi siswa sekolah dasar. Untuk mencapai tujuan tersebut maka metode yang dilakukan dalam kegiatan ini adalah melalui beberapa tahapan, yaitu tahap pertama observasi ke lapangan secara langsung dan koordinasi dengan pihak pihak terkait dalam kegiatan ini. Tahap yang kedua memberikan pelatihan Shuttle Time kepada guru olahraga SD.

Pelatihan akan dilaksanakan 3 hari kemudian tahap ketiga adalah para guru akan langsung memberikan materi Shuttle Time kepada para siswanya masing-masing selama 2 hari. Selanjutnya tahap keempat adalah Tindak lanjut yaitu melaksanakan kompetisi antar siswa binaan dari masingmasing guru olahraga dan membentuk wadah pengembangan diri dari para siswa yang ingin berprestasi pada cabang olahraga bulutangkis melalui klub olahraga bulutangkis yang membina atlet muda berbakat di Kabupaten Sijunjung.

\section{PENGAKUAN}

Terima kasih di sampaikan kepada ISORI Kabupaten Sijunjung yang telah memfasilitasi proses pelatihan Shuttle Time, dengan menyediakan tempat pelaksanaan dan mengkoordinir peserta. Terima kasih kepada MGMP (Musyawarah Guru Mata Pelajaran) PJOK yang telah menyebarkan informasi pelatihan ini serta terima kasih kepada rekan-rekan dari beberapa sekolah dasar di Kabupaten Sijunjung yang terlah bersedia mengikuti kegiatan ini.

\section{DAFTAR PUSTAKA}

Asnaldi, A. (2019). Panduan Pelatihan Komponen Motor Ability Bagi Pelatih Lemkari Dojo Angkasa Lanud Padang. ResearchGate.

https://www.researchgate.net/publication/332709190_Panduan_Pelatihan_Komponen_Motor_Ab ility_Bagi_Pelatih_Lemkari_Dojo_Angkasa_Lanud_Padang

Asnaldi, A., Yelis, R., Zulman, Atradinal, Putri, L. P., \& Bakhtiar, S. (2020). The Differences of 
Journal Humanities: Jurnal Pengabdian kepada Masyarakat Volume 2, Nomor 1, Bulan Juni, 2021. E - ISSN 2715-5471

Doi: https://doi.org/10.24036/jha.0201.2021.03

Ability in the Level of Development on Control Objects of Early Childhood Education Students in Pariaman City and Padang Panjang City. Proceedings of the 1st International Conference of Physical Education (ICPE 2019), 97-100. https://doi.org/10.2991/assehr.k.200805.028

Barnett, F., \& Thomas, Y. (2012). The impact of exercise on the mental health and quality of life of people with severe mental illness : a critical review. March 2014, 47-60. https://doi.org/10.4276/030802212X13286281650956

BPS. (2018). No Title.

Didik Rilastiyo Budi, Arfin Deri Listiandi, Rifqi Festiawan, Neva Widanita, D. A. (2020). Indeks Masa Tubuh (IMT): Kajian Analisis Pada Atlet Renang Junior Usia Sekolah Dasar Didik. Journal of Teaching Physical Education in Elementary School, 3(2), 46-53. https://doi.org/https://doi.org/10.17509/tegar.v3i2.24452

Drachsler, H. (2011). Learner Characteristics. January. https://doi.org/10.1007/978-1-4419-1428-6

Glasow, P. (2005). Fundamentals of Survey Research Methodology.

Harackiewicz, J. M., \& Hulleman, C. S. (2010). The Importance of Interest : The Role of Achievement Goals and Task Values in Promoting the Development of Interest. 1, 42-52.

Harper, S. (2012). The Leader Coach: A Model of Multi-Style Leadership. Journal of Practical Consulting, 4(1), 22-31.

Kirca, A. H., Jayachandran, S., \& Bearden, W. (2005). Market Orientation : A Meta-Analytic Review and Assessment of Its. April. https://doi.org/10.1509/jmkg.69.2.24.60761

Omar, D., \& Aman, M. S. (2009). Sports Facilities Development and Urban Generation. April. https://doi.org/10.3844/jssp.2009.460.465

Osborne, R. E. (2013). Journal of Online Learning and Teaching It Can Be Taught : Explorations into Teaching the Foundations for Multicultural Effectiveness in an Online Course. December.

Papa, S. (2017). The Effects of Physical Activity on Social Interactions : The Case of Trust and Trustworthiness The Effects of Physical Activity on Social Interactions : The Case of Trust and Trustworthiness. July. https://doi.org/10.1177/1527002517717299

Science, I., Queen, H., \& Queen, H. (2013). Guideline adaptation and implementation planning : A prospective observational study. December 2016. https://doi.org/10.1186/1748-5908-8-49

Takaloo, N. M., \& Ahmadi, M. R. (2017). The Effect of Learners 'Motivation on Their Reading Comprehension Skill : A Literature Review. 10-21.

Woodward, M. (2011). SHUTTLE TIME. BWF Journal. 